\title{
Bilateral Globus Pallidus Internus Deep Brain Stimulation in Parkinson's Disease with Periodic Limb Movement Disorder
}

\section{Periyodik Uzuv Hareketi Bozukluğu ile Parkinson Hastalı̆̆ında Bilateral Globus Pallidus Internus Derin Beyin Stimülasyonu}

\author{
Bryan T. KLASSEN ${ }^{1}$, Mark K. LYONS ${ }^{2}$, Virgilio Gerald H. EVIDENTE ${ }^{1}$ \\ ${ }_{1}^{1}$ Mayo Clinic Arizona, Departments of Neurology, Phoenix/AZ, USA \\ ${ }^{2}$ Mayo Clinic Arizona, Departments of Neurological Surgery, Phoenix/AZ, USA
}

Correspondence address: Mark LYONS / E-mail: lyons.mark2@mayo.edu

\begin{abstract}
Deep brain stimulation for Parkinson's disease is a well-established therapeutic intervention for refractory disease. The main nuclear targets are the subthalamic nucleus and the globus pallidus internus. Periodic limb movements are often an associated condition in patients with Parkinson's disease. Both conditions can respond to dopaminergic agents. The case of a 57-year-old man with severe Parkinson's disease and periodic limb movement who underwent bilateral globus pallidus deep brain stimulation surgery for his Parkinson's disease is presented and discussed. Intraoperatively the patient's periodic limb movements responded to voltage stimulation higher than those required for improvement of his parkinsonian symptoms. The immediate and reversible improvement in these symptoms contralateral to the stimulation site suggests pallidal stimulation may directly ameliorate periodic limb movement symptoms.
\end{abstract}

KEYWORDS: Deep brain stimulation, Globus pallidus, Parkinson's disease, Periodic limb movements

öz

Parkinson hastalığı için derin beyin stimülasyonu refrakter hastalıkta iyi yerleşmiş bir terapötik girişimdir. Ana nükleer hedefler subtalamik nükleus ve globus pallidus internustur. Periyodik uzuv hareketleri Parkinson hastalıklı hastalarda sıklıkla ilişkili olarak görülen bir durumdur. Her iki durum dopaminerjik ajanlara cevap verebilir. Burada şiddetli Parkinson hastalığı ve periyodik uzuv hareketi olan ve Parkinson hastalığı için bilateral globus pallidus derin beyin stimülasyonu cerrahisi yapılan 57 yaşında bir erkek hastayı sunuyoruz. İntraoperatif olarak hastanın periyodik uzuv hareketleri, Parkinson belirtilerinin düzelmesi için gerekli olandan daha yüksek voltaj stimülasyonuna cevap verdi. Stimülasyon bölgesine kontralateral bu belirtilerin anında ve geri çevrilebilir şekilde düzelmesi pallidal stimülasyonun periyodik uzuv hareketi belirtilerini doğrudan iyileştirebileceğini düşündürmektedir.

ANAHTAR SÖZCÜKLER: Derin beyin stimülasyonu, Globus pallidus, Parkinson hastalığı, Periyodik uzuv hareketleri

\section{INTRODUCTION}

Patients with Parkinson's disease (PD) undergoing deep brain stimulation (DBS) surgery often have many comorbid conditions. Periodic limb movements (PLM) is frequently associated with restless legs syndrome (RLS) and Parkinson's disease. The symptoms of PLM are generally repetitive stereotypical involuntary movements similar to the spinal cord flexor reflex. They more often occur during sleep at intervals of 5 to 90 seconds (7). Periodic limb movements may occur during sleep (PLMS) and, although less commonly, during wakefulness (PLMW) $(7,15)$. These symptoms can be very bothersome to patients. We report a case of a PD patient who underwent successful bilateral globus pallidus internus (GPi) deep brain stimulation for treatment of medically refractory parkinsonism and also experienced voltagedependent improvement in PLMW.

\section{CASE REPORT}

A 57-year-old man with a history of medically refractory PD underwent bilateral GPi DBS for his disease. In addition, the patient also experienced RLS and PLM both while asleep and awake. The surgical procedure was performed under local anesthesia, with intravenous administration of minimal amounts of conscious sedation and analgesic medications. A magnetic resonance (MR) compatible headframe was applied to the patient's head and MR imaging was performed using a 1.5 tesla machine. He underwent staged bilateral stereotacticguided globus pallidus internus deep brain stimulation surgery using the COMPASS ${ }^{\circledR}$ stereotactic system. The targeting coordinates were $2 \mathrm{~mm}$ anterior and $2 \mathrm{~mm}$ inferior to the midcomissural point and $20 \mathrm{~mm}$ lateral to the midpoint of the third ventricle. Microelectrode recordings were done beginning $20 \mathrm{~mm}$ above the target using 5 concentric 
bipolar tungsten microelctrodes driven simultaneously by a hydraulic Alpha-Omega ${ }^{\circledR}$ microdrive at incremental depths of 0.3 to $0.5 \mathrm{~mm}$. Microelectrode recordings were followed by microstimulation in order to localize the best depth and trajectory. Subsequent implantation of Medtronic ${ }^{\circledR}$ quadripolar 3387S DBS electrodes was performed. Macrostimulation was done to further refine final electrode placement based upon intraoperative effect. Postoperative brain MR confirmed placement of the electrode tips in the GPi (Figure 1).

We have previously reported improvement in RLS symptoms in patients with Parkinson's disease who underwent bilateral subthalamic nucleus (STN) DBS (5). In this case, the patient was also symptomatic from his RLS and PLM. Prior to the surgery, the patient was tapered off of his ropinirole and levodopa dose increased. He reported exacerbation of RLS and PLM. As his levodopa was withheld the night before his surgery, the patient experienced worsening symptoms in the operating room prior to implantation. Stereotypical repetitive lower limb movements consistent with PLMW were observed at a frequency of 4-6 per minute on the right side and 2.5-3 per minute on the left side. The diagnosis of PLMW requires the expertise of sleep medicine physicians or movement disorder specialists. The patient underwent simultaneous intraoperative electrophysiologic monitoring and video recording by two experienced movement disorder specialists confirming the diagnosis of PLMW. Frequencies of the movements were similar at rest and when the patient was engaged in mental or motor tasks. The patient reported no sense of voluntary control over these movements.

Intraoperative macrostimulation was used to optimize clinical benefit and exclude limiting side effects. The settings were

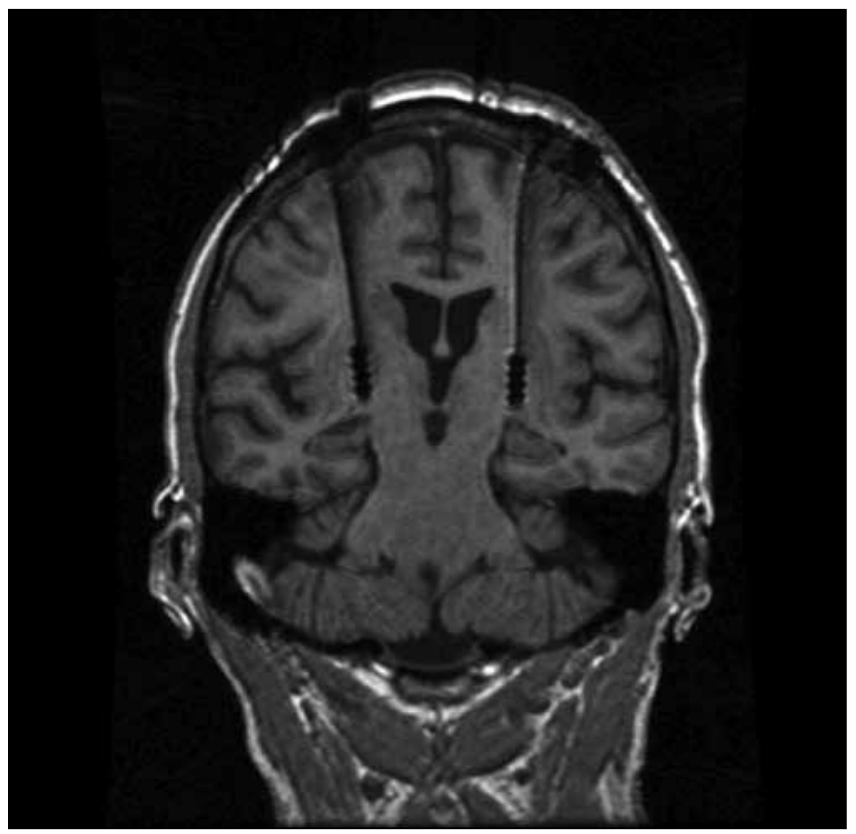

Figure 1: Coronal T-1 weighted MR image demonstrating bilateral electrode placement in the globus pallidus internus. the same on both sides using contact 0 negative, contact 3 positive, pulse width of 120 microseconds, rate of $185 \mathrm{~Hz}$, and gradually increasing amplitudes. The threshold for significant improvement of the right-sided parkinsonian symptoms of rigidity and bradykinesia with left GPi stimulation was 2.5 volts. At an amplitude of 3 volts, PLMW symptoms substantially abated on the patient's right side and right foot dyskinesia emerged with an increase to 3.5 volts. When left GPi macrostimulation was discontinued, the PLMW symptoms returned. There was no observed effect or change of the PLMW symptoms on the left side with or without left GPi stimulation. At the subsequent surgery, the threshold for relief of left-sided parkinsonism with right GPi stimulation was 2 volts. Left-sided PLMW symptoms abated at an amplitude of 3 volts. Following termination of stimulation, PLMW returned bilaterally to their baseline frequencies. One month postoperatively, programming was optimized for control of the PD symptoms. The patient's PD medication doses were reduced from $925 \mathrm{mg}$ levodopa equivalents pre-DBS to 100 $\mathrm{mg}$ at one month post-DBS. At that time, his PLMW symptoms had fully resolved. On last follow-up two years post-DBS, his PD medications were 133 levodopa equivalents, and he continued to have significant relief of his PD symptoms as well as his PLMW.

\section{DISCUSSION}

It is unclear if there is any pathophysiologic connection between PD and RLS or PLM (1). There is no consensus agreement on the pathogenesis of PLM. However, the excellent response of PLM to dopaminergic medications and worsening of symptoms with dopamine receptor blocking agents suggests the dopamine system is playing a role in the development of PLM. The dopaminergic theory in the pathogenesis of PLM has been supported by single photon emission computerized tomography (SPECT) and positron emission tomography (PET) studies $(12,14)$. Nigrostriatal presynaptic dopamine hypofunction and decreased D2 receptor binding in patients with PLM and RLS have been reported $(9,12,14)$. The dopamine abnormality resulting in dysfunction of the nigrostriatal pathway may play a role in the pathogenesis of PLM (8). Response of RLS symptoms in PD patients following STN DBS and pallidotomy has been reported $(5,10,13)$. However, polysomnography studies measuring the PLM index in PD patients who have undergone STN DBS have been variable $(2,4,6)$. The marked reduction in contralateral movements and nearly immediate reversibility of the observed effect in this patient with intraoperative stimulation suggest that perhaps PLM may be potentially responsive to GPi DBS. The withdrawal of the dopaminergic medications preoperatively may have enhanced the intraoperative observations of this patient's PLMW symptoms. There is data suggesting that PLM may be mediated at the level of the spinal cord $(3,11)$.

Interestingly, in this case, the threshold of stimulation to abate the PLM symptoms was higher than customarily required for improvement of PD symptoms alone. This observation may 
partially explain the lack of response of PLM symptoms in STN DBS patients where programming was optimized for the PD symptoms. Even though both STN DBS and GPi DBS are both beneficial for PD, it remains a possibility the GPi stimulation may have a different effect on PLM symptoms than STN stimulation. Lee and co-workers reported a case of a 58-yearold man suffering an acute infarct of the posterior limb of the internal capsule with involvement of the adjacent pallidum (7). He subsequently developed nocturnal stereotypical periodic involuntary movements of the contralateral leg. Marked improvement was noted upon initiation of levodopa and carbidopa. Discontinuation of the medication resulted in return of the PLM symptoms (7). Similarly, the pathophysiology of RLS and resultant limb pain is thought to be related to abnormality of central dopaminergic transmission (10). Clearly, substantial more work and experience with DBS in patients with PLM is necessary before any conclusions can be drawn.

\section{REFERENCES}

1. Adler $\mathrm{CH}$, Thorpy MJ: Sleep issues in Parkinson's disease. Neurology 64(12 Suppl 3):S12-20, 2005

2. Arnulf I, Bejjani BP, Garma L, Bonnet AM, Houeto JL, Damier P, Derenne JP, Agid Y: Improvement of sleep architecture in PD with subthalamic nucleus stimulation. Neurology 55(11):1732-1734, 2000

3. Bara-Jimenez W, Aksu M, Graham B, Sato S, Hallett M: Periodic limb movements in sleep: State-dependent excitability of the spinal flexor reflex. Neurology 54(8):1609-1616, 2000

4. Cicolin A, Lopiano L, Zibetti M, Torre E, Tavelle A, Gusastamacchia G, Terreni A, Makrydakis G, Fattori E, Lanotte MM, Bergamasco B, Mutani R: Effects of deep brain stimulation of the subthalamic nucleus on sleep architecture in parkinsonian patients. Sleep Med 5(2):207-210, 2004

5. Driver-Dunckley $\mathrm{E}$, Evidente $\mathrm{VGH}$, Adler $\mathrm{CH}$, Hillman $\mathrm{R}$, Hernandez BA, Fletcher G, Lyons MK: Restless legs syndrome in Parkinson's disease patients may improve with subthalamic stimulation. Mov Disord 21(8):1287-1289, 2006
6. Iranzo A, Valldeoriola F, Santamaria J, Tolosa E, Rumia J: Sleep symptoms and polysomnographic architecture in advanced Parkinson's disease after chronic bilateral subthalamic stimulation. J Neurol Neurosurg Psychiatry 72(5):661-664, 2002

7. Lee JS, Lee PH, Huh K: Periodic limb movements in sleep after a small deep subcortical infarct. Mov Disord 20(2):260-261, 2005

8. Lindvall O, Bjorklund A, Skagerberg G: Dopamine-containing neurons in the spinal cord: anatomy and some functional aspects. Ann Neurol 14:255-260, 1983

9. Michaud M, Soucy JP, Chabli A, Lavigne G, Montplasir J: SPECT imaging of striatal pre- and postsynaptic dopaminergic status in restless legs syndrome with periodic leg movements in sleep. J Neurol 249:164-170, 2002

10. Okun MS, Fernandez HH, Foote KD: Deep brain stimulation of the GPi treats restless legs syndrome associated with dystonia. Mov Disord 20(4):500-501, 2005

11. Paradiso G, Khan F, Chen R: Effects of apomorphine on flexor reflex and periodic limb movement. Mov Disord 17(3): 594-597, 2002

12. Ruottinen HM, Partinen M, Hublin C, Bergman J, Haaparanta M, Solin O, Rinne JO: An FDOPA PET study in patients with periodic limb movement disorder and restless legs syndrome. Neurology 54:502-504, 2000

13. Rye DB, DeLong MR: Amelioration of sensory limb discomfort of restless legs syndrome by pallidotomy. Ann Neurol 46: 800-801, 1999

14. Staedt J, Stoppe G, Kogler A, Riemann H, Hajak G, Munz DL, Emich D, Ruther E: Single photon emission tomography (SPET) imaging of dopamine D2 receptors in the course of dopamine replacement therapy in patients with nocturnal myoclonus syndrome (NMS). J Neural Transm Gen Sect 99:187-193, 1995

15. Trenkwalder C, Walters AS, Hening W: Periodic limb movements and restless legs syndrome. Neurol Clin 14(3):629-650, 1996 